B.A.J. 7, II, 311-312 (2001)

\title{
MEMOIR
}

\section{DAVID DOUGLAS MCKINNON}

Born on 18 July 1926 in Larbert, Stirlingshire, the youngest of three brothers, Douglas McKinnon was educated at the High School of Stirling and then at the University of Glasgow. He graduated in 1946 with first class honours in mathematics and natural philosophy, winning the Joseph Black Medal (chemistry) in 1944, the Isaac Newton Medal (natural philosophy) in 1945, and the Cunninghame Medal for the best student in mathematics in 1946.

He began his working career as a mathematics lecturer at his alma mater, but fairly quickly decided to change from the academic to the business community. In 1948 he joined the Scottish Temperance and General Assurance Company Ltd. — which later became the Scottish Mutual. He enrolled as a student of the Faculty of Actuaries, and was one of the select few who demonstrated, by application and not a little ability, that it was possible to pass all the examinations for the Fellowship of the Faculty in the then amazingly short time of three years.

He served Scottish Mutual with distinction in various appointments, culminating in his promotion to the chief executive's position in 1982. Despite a heart attack later that year and a subsequent bypass operation, he was soon back in full swing. Under his leadership, Scottish Mutual was involved and prospered in the vastly changing conditions that affected the financia services industry in the United Kingdom at that time. Not least was his determination to make Scottish Mutual a leading player in the rapidly growing markets for unit-linked life and pension contracts by pioneering the controlled risk type of products. He also had to contend with the enormous changes in working practices as a result of the Financial Services Act, and spent many hours on industry committees in this connection. Another of his contributions to the whole insurance industry was his involvement, over many years, with committees considering the implications of various European Directives. He retired from his executive position in 1990, but continued to serve as a director until his seventieth birthday in 1996. During this latter period he played an important part in Scottish Mutual's demutualisation and acquisition by Abbey National.

He repaid his debt to the actuarial profession many times over. He served first as a tutor then for 13 years as an examiner, the last five of these as Chairman of the Examination Board He had various spells on the Faculty Council, culminating in the well-deserved honour of being elected President of the Faculty in 1979. For many years he was the Faculty representative on the committee of the International Actuarial Association. However, despite the many pressures on his time, he was always a very regular attender at Faculty sessional meetings, and continued to attend right up until his death.

He was a dedicated member of the Boys' Brigade movement - first as a boy, then as an officer in the 1st Larbert Company, and later in the Falkirk \& District Battalion, where he was President from 1972 to 1977. Perhaps not surprisingly, related to this was his lifelong interest in the church, both locally and nationally. He was baptised in Larbert West Parish Church, and remained connected to that church until his death. He was Treasurer from 1964 to 1969, and then, like his father before him, became Session Clerk, a position he held for the next 19 years. He remained closely involved, and in his retirement produced a detailed history of the church to mark its centenary in 1998. But that was by no means his only contribution to church affairs, as he served the wider church in various capacities.

He was a member of the Falkirk Presbytery for the past nine years, serving on the Finance Committee and latterly as its Convenor. Not surprisingly, he came to the attention of those in the ' 121 ' headquarters of the Church of Scotland, becoming a member of the Church of Scotland Trust as far back as 1974, and its Chairman from 1991 to 1996. Indeed, he was on his way to a Trust meeting on 23 January 2001 when he collapsed and died in Castle Street, Edinburgh. He 
held various other positions, including being a member of the Kirk's Assembly Council from 1987 to 1996, and of the Board of Stewardship and Finance from 1996 until his death. He had a very clear mind, and possessed the all too rare ability to express and explain even complex issues in ways that 'financial amateurs' could understand. Furthermore, it is said that he had the knack of making even church committee meetings both educational and entertaining.

He married in 1960, and his wife, June, has been a tremendous support to him throughout the subsequent years. An accomplished person in her own right, June provided the background which complemented her husband's business and professional activities and at the same time raised their family of two daughters and one son, who survive him. In the preface to the centenary history of his church, Douglas wrote: "Finally, and not least, I thank my wife, June. She could have expected, during my retirement, to be relieved of the clutter of my activities, but she has tolerated this further intrusion into our domestic life and supported me in the same helpful way as she has done in all my work." That says it all.

One might have thought that, with all his other commitments, there would have been little room for recreational activity. Yet, in his early days as a Boys' Brigade officer, he was to be found refereeing B.B. football matches in the Falkirk area. Also, like so many other youngsters in the Larbert area, he became a member of Falkirk Tryst Golf Club, and later of Glenbervie Golf Club. In his usual methodical way, he started on the right lines by taking a course of lessons from that master of the links and delightful gentleman, John Panton, then the professional at Glenbervie, and after each lesson, Douglas went home and wrote down what the 'maestro' had told him and shown him. This laid the foundation of a useful swing and a love for the game, which he continued to enjoy over the years. Many of his contemporaries can recall the pleasure of his companionship and his knowledge of the rules of golf, which sometimes they would rather not have heard, because of the adverse effect on their score.

In all that he did he gave of his best, often way beyond the call of duty. He had high standards, and he was a stickler for detail. Despite having a wonderful memory, he always carried around a small notebook, and jotted down things of interest or to be done, and if he promised to do something, he did it! He was always punctual, and expected others to be so. "If the Kirk service is timed for 11 a.m. then it should start at 11 a.m." A business colleague once remarked that Douglas was a 'man of moderate views expressed forcibly'. But, most importantly, in all things he was full of understanding and compassion. There are countless people - in all the areas touched by him - who have been grateful for his help and advice. He was a thoroughly likeable person, and it was a privilege to know him - a fact well demonstrated by the huge turnout at his funeral service held in his beloved Larbert West Church. 